\title{
The Career Path of Expatriates at Repatriation
}

\author{
Yanghua Zhou
}

\begin{abstract}
Increasing globalization in the economic and other social areas has led to more and more expatriate assignment. Because much of this expatriate assignment has some problems, expatriates' career has been respected very much. Many scholars consider that it has significant relation with expatriates' psycological contract. By reviewing expatriate career management related literature (Career Theory and Psycological Contract related researches) and analyzing through three dimensions (individual, organizational and global envionment), this research offers a theoretical framework with 4 propositions for future research on expatriate career path at repatriation.
\end{abstract}

Index Terms-Career, expatriate, psycological contract, repatriation.

\section{INTRODUCTION}

In recent years, because expatriates play important roles in multinational corporations (MNCs), their repatriation success, as one process in their international career after expatriation, has been respected more and more. Some expatriates quit in their expatriation period, which brings risk and disadvantage to their multinational organizations. On the other hand, some expatriates are repatriated as scheduled but finally they find there is no fitful job in their headquarters any more. And this will makes individuals disappointed and their motivation will decline. Yan, Zhu \& May (2002) analyzed these phenomena from the view point of psychological contracts [1]. By considering dual effect from individual and organizational perspectives, he pointed out how the psychological contracts (relational contracts \& transactional contracts) of expatriates and their multinational organizations influence the degree of repatriation success. However, in previous literature, there is a lack of detailed theoretic analysis of the repatriation success degree of different individuals, for example, what is the repatriation success degree of expatriates in middle career stage? And how about individuals in other career stages? And how will they change their psychological contracts? In the past, theoretical research on these questions has not got enough conclusions and they will be answered in this study.

\section{LITERATURE REVIEW}

\section{A. Why a Multinational Corporation Uses Expatriates}

According to Tan (2006), 'Expatriates are home-country nationals (i.e. citizens of the country in which the multinational firm is headquartered) who are sent by the

Manuscript received December 9, 2013; revised February 1, 2014.

Yanghua Zhou is with the Graduate School of Policy Studies, Chuo University in Tokyo, Japan (e-mail: tsuruyoko@gmail.com). headquarters to the foreign positions' to accomplish the transference of technology or knowhow from the headquarters to subsidiaries and the subsidiary management within 3 or 5 years or longer period [2].

From the viewpoint of agency and transaction costs theories, in a multinational firm, there is principal-agent relationship between headquarter and its subsidiary. According to Tan (2006), using expatriates is a governance choice for offering managerial services in foreign branches, and this governance choice is usually considered for reducing the agency and transaction economic costs from managers of foreign branches [2]. From the agency theory's point of view, Tanzawa (2000) noted there are three types of asymmetric information problems: 'adverse selection, moral hazard and hold up' [3]. Tan (2006) pointed out that the multinational corporations have to reduce communication cost and asymmetric information problems between the headquarters and their foreign subsidiaries by sending expatriates to important positions in their foreign branches [2], [4]. From the viewpoint of transaction costs theory, multinational corporations will assign expatriates to reduce bargaining problems to some extent.

Furthermore, Erdener (1999) pointed out that from the perspective of transaction cost economics, using expatriates may reduce culture frictions and risk so that multinational corporations are able to get competitive advantage and improve their performance [5]. Additionally, based on an empirical study of 145 Norwegian multinational corporations, Gabriel (2005) stated that according to transaction cost theory, using expatriates may reduce transaction cost, especially when using experienced expatriates [6]. He also observed that culture differences between host and home countries will influence the ex post transaction cost of multinational corporations.

From the perspective of 'Multi-national Internal Labor Markets' theory (see Fig. 1), Shiraki (2006) stated that sufficient basic human resource in subsidiaries of a multinational corporation is a necessary condition for the formation of Multi-national Internal Labor Markets [7]. According to Shiraki (2006), Internal Labor Markets are those where workers are hired into entry level jobs and higher levels are filled from within. Without internal labor market in a multinational corporation, human resource management may have some serious problems [7]. For instance, if some foreign subsidiary of a multinational corporation is in lack of knowhow or technology in some field, it can send an expatriate there to fill this gap soon. But if its internal labor market is not regular, it will take a lot of time to search such a suitable person to accomplish this job. Hence, expatriate assignment becomes an important part of international human resource management strategy.

Discussed as above, both 'Multi-national Internal Labor Markets' theory and agency and transaction cost theory 
suggest that it is necessary for multinational corporations to use expatriate assignment.

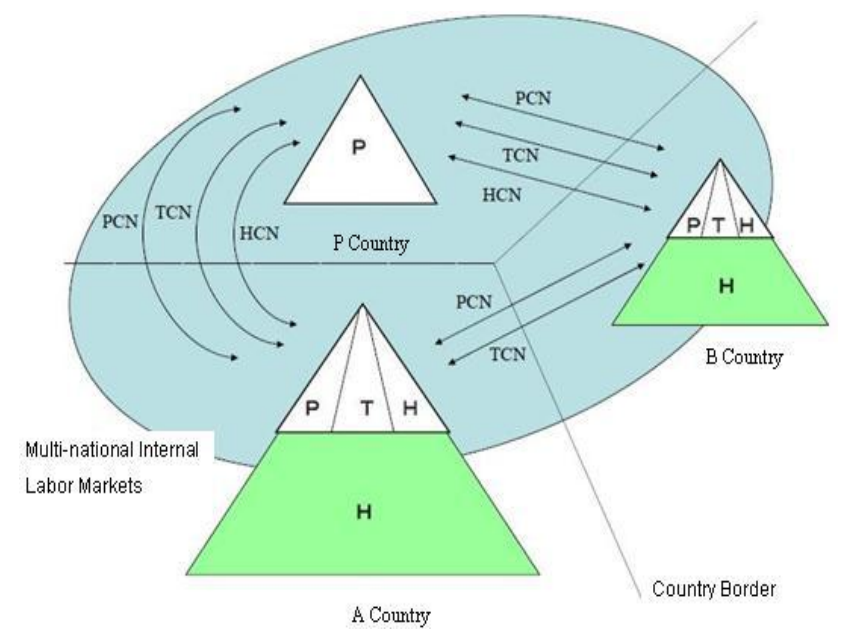

Note: P Country represents parent company country. PCNs (or P) represents parent-country nationals, $\mathrm{HCNs}$ (or $\mathrm{H}$ ) represents host-country nationals, TCNs (or T) represents third-country nationals.

Source: Shiraki (2006), An analysis of International Human Resource Management: From the 'Multi-national Internal Labor Markets' Viewpoint, p28 [7].

Fig. 1. Multi-national internal labor markets.

\section{B. Careers Related Previous Literature}

The definition of career is "the evolving sequence of a person's work experiences over time" (Arthur, Hall \& Lawrence, 1989)" [8]. Career is influenced deeply by a person's age. According to Schien (1978), career is divided into several stages: initial stage (<30years old), middle stage (from 30 years old to 45 years old) and later stage [9]. And according to Liu (2002), career is divided into four stages: exploration stage (<30years old), determining stage (from 30 years old to 45 years old), maintenance stage (from 45 years old to 55 years old), declining stage ( $>55$ years old) [10].

Employees in different career stages have distinct characteristics. For employees from 30 years to 45 years, their career searching actions has stopped, and what they expect most is promotion, training and fair compensation. At this career stage, their potential and capability for their organization are still not easy to judge. For the employees that are more than 55 years old, some of them have to leave their organizations because they want to retire. On the other hand, some of them have the willingness to stay and serve for their corporations continuously, but they cannot work on a fulltime job for some health problems or their salary are cut to half of the past for their age. Of course, some of them are elites of their organizations and have been or are highly possible to become the directors of the multinational corporations or group companies. The characteristics of this career stage are that they have mutual loyalty with their organizations but some of them maybe cannot act as expected by themselves any more.

Many people work as an engineer for lifelong in the same company and they spend their lives in a kind of technician career. On the contrary, many people work as engineers first, then after five years they quit to other companies even other countries and work as managers or other kind of jobs. Nowadays, there are a lot of different kinds of careers, especially in this globalization generation.

There are many factors that influence career path and they can mainly be divided into two categories: organizational reasons and individual reasons. Therefore, there are self-initiated careers and organization-initiated careers. Organizational reasons refer to organization size, years in operation, category of industry, and its human resource management system etc. On the other hand, expatriates' career will also be influenced by their own internal factors, such as an individual's age, job type, experience, career attitude, career objective, self-efficacy, self-adjustment, performance and other career capital (Okubayashi, Hirano, 2004) [11]. Career capital means knowing-how, knowing-whom and knowing-why (Vesa, 2007) [12]. According to Kristina \& Vesa (2009), knowing-how refers to necessary skills, expertise, and knowledge for one's job and long-term career, while knowing-who mainly is the personal network. And knowing-why means view of values, motivation, understanding of the work and self-awareness etc. [13].

Furthermore, an individual's career can be influenced by his or her outside environment, such as culture distance (Cao, Hirschi, And Deller, 2012) [14] and globalization environment (Yan, Zhu, \& May, 2002) [1]. Additionally, there are organizational-individual alignment reasons, such as psychological contract, which will be analyzed in the following content.

To summarize, one's career is influenced by many elements of several aspects. The age effect among them is very important and it is a basic main factor. In this study, the influence of one's age to an expatriate's career in the repatriation period will be discussed in the theoretic framework.

\section{Expatriate' Repatriation and Career in Globalization}

In the globalization generation, external factors that influence expatriates' career include overseas business withdrawal, M\&A, restructure and others. Therefore, in this globalization circumstance, there have happened a lot of changes in expatriates' career. For instance, higher career mobility and decreasing commitment (Inkson, Arthur, Pringle and Barry 1997) [15]. According to David, Mila and Kerr (2005), a number of changes in the international business environment makes careers more global. Specifically, it becomes necessary for more and more companies to develop global leaders, which forces the tasks of expatriate become routine [16]. This makes the career mobility increase gradually (Suutari and Brewster 2000) [17].

Furthermore, the increasing expatriate assignment brings different new career concepts to expatriates, such as boundary-less career - not only to serve for one organization or country- (Ursula \& Nicholas, 2009) [18], global career and protean career - more inter-organizational mobility and self-initiated- ((Yan, Zhu \& Hall, 2002) [1], (Hall, 1976) [19] \& (Hall \&Associates, 1996) [19]). According to Arno and Chris (2009), the international expatriate assignment restructures an expatriate's career capital [21].

The globalization related factors raise many problems in expatriates' career, especially in repatriation. Hence, some 
expatriates quit before finishing their expatriation period. It is possible for them to find better jobs in another organization or another country. On the other hand, some expatriates are repatriated as scheduled but finally they find there is no fitful job in their headquarters.

\section{Psychological Contracts}

The concept of psychological contract means "employees' perceptions and expectations of the mutual obligations that exist between themselves and the employing organization." (Rousseau, 1989) [22]. The expectations from individual to organization includes promotion, high salary, training, long-term employment, career development and other support. On the contrary, the expectations from organization to individual include overtime work, loyalty, good performance, contents unwritten in job description, capability of transfer, maintaining confidentiality, minimum years of service (Rousseau, 1990) [23]. Compared with paper-based contracts, psychological contracts have the characteristics of implicit, unwritten, and informal in most cases. And a psychological contract represents critical mutual expectations held by the two parties of individuals and their organizations (Schein, 1965) [24].

Through meta-analysis of the relationship between psychological contract fulfillment and its result, Zhao, Wayne, Glibkowski and Bravo (2007) suggested that psychological contract breach has negative impact on job satisfaction, organization commitment, resignation notion, organizational citizenship behavior and performance of an individual [25]. Therefore, psychological contracts affect expatriates' career selection when they think of repatriation. They will consider whether they should go back to headquarters or quit to other multinational corporations. Marius, Gudela, Christian, and Sabine (2012) also got a similar conclusion by an empirical study [26].

According to MacNeil (1985), psychological contracts are divided into two types: relational contracts and transactional contracts. Relational contracts refer to short-term job and project oriented expectation, and transactional contracts refer to a long-term loyalty based expectation [27]. Additionally, besides relational contracts and transactional contracts, other forms of contract are also possible, such as balanced contracts (Rousseau, 2000) [28]. According to Liu (2002), Employees in different career stages have distinct characteristics of psychological contracts. In the determining stage of one's career (from 30 years old to 45 years old), an employee views the relationship with his/her organization as transactional; in the maintenance stage (from 45 years old to 55 years old), an employee views it as balanced, and in the decline stage (>55 years old) an employee views it as relational.

Wang (2013) argued that individual's culture characteristic can influence one's sense of value and then have impact on his/her psychological contracts [29]. He pointed out that employees in the culture that has individualism characteristic is easy to have transactional contracts. And individuals in collectivism culture have the tendency of taking relational contracts. In this study, individuals and organizations in individualism culture circumstance are the research objects.

\section{E. Psychological Contracts' Effect on Expatriates' Career}

Yan, Zhu \& May (2002) proposed an Organization-Individual Alignment Matrix (as shown in Table I) by analyzing psychological contracts (relational contracts and transactional contracts) of both organizations and individuals [1]. And based on the psychological contract alignment, the degree of repatriation success was suggested. Therefore, there are different career patterns in expatriates' repatriation. Furthermore, because psychological contracts are easy to be changed, possible external causal factors in shift-in are also proposed in their paper. Through an empirical study, Arno and Chris (2009) also emphasized that during the repatriation period there is a stronger link between a perceived breach and turnover cognitions than at other times in the employment relationship [21].

These researches are good references for us researchers when considering the careers at repatriation of expatriates. But when an expatriate will view the contract as relational or transactional is still unclear. It is the same that when the multinational organizations will view the relationship as relational or transactional. Hence, in this study, these questions will be answered by a theoretic analysis based on career theory and psychological contract theory. Additionally, internal factors that influence the organization's psychological contracts will also be proposed.

TABLE I: ORGANIZATION-INDIVIDUAL ALIGNMENT MATRIX

\begin{tabular}{|c|c|c|c|}
\hline & & \multicolumn{2}{|c|}{ Organization } \\
\hline & & Relational & Transactional \\
\hline \multirow[b]{2}{*}{ 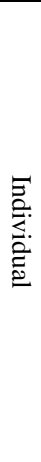 } & 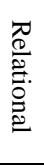 & $\begin{array}{l}\text { I } \\
\text { High organizational } \\
\text { success in repatriation } \\
\text { High individual } \\
\text { success in repatriation }\end{array}$ & $\begin{array}{l}\text { III } \\
\text { Low organizational success } \\
\text { in repatriation } \\
\text { individual failure in } \\
\text { repatriation }\end{array}$ \\
\hline & 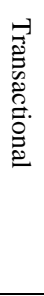 & $\begin{array}{l}\text { II } \\
\text { Organizational failure } \\
\text { in repatriation } \\
\text { mixed individual } \\
\text { success in repatriation }\end{array}$ & $\begin{array}{l}\text { IV } \\
\text { A better chance of } \\
\text { organizational success in } \\
\text { repatriation than that in the } \\
\text { case of misalignment } \\
\text { A better chance of } \\
\text { individual success in } \\
\text { repatriation than that in the } \\
\text { case of misalignment }\end{array}$ \\
\hline
\end{tabular}

Notes: Organizational success in repatriation: Retention of repatriated employee; Utilization of new expertise; Transfer of expertise. Individua success in repatriation: Continued development; Attractive future assignments; Promotion; Enlargement of responsibility.

Source: [1].

\section{THEORETICAL FRAMEWORK}

According to Yan, Zhu \& May (2002), an individual's repatriation success refers to long-term career growth and continued development opportunities after repatriation, for instance, promotion and challenging tasks. And the most important thing for an organization's repatriation success is effective future utilization of new expertise, for instance, using the expatriate's learning or transferring it to other individuals [1].

Based on the above-mentioned theoretic analysis and previous literature review, in the following contents, the framework of this study will be discussed as Table II indicates. 
Proposition 1: For expatriates of 30-45 years old that are considered as elites, their multinational corporations will view the psychological contracts between them as relational.

Proposition 2: For expatriates of 30-45 years old that are not considered as elites, their multinational corporations will view the psychological contracts between them as transactional.

As Liu (2002) suggested, in the determining stage of one's career (from 30 years old to 45 years old), an employee views the relationship with his or her organization as transactional [10]. In this career stage, an expatriate in individualism culture circumstance will try to learn a lot of knowledge and is interesting in career opportunities outside his or her multinational corporation. If there is better learning chance or career path or position with higher compensation, it is easy for him or her to quit to another company. The possibility that they won't come back to their headquarters as scheduled is very high. Their psychological expectations are not easy to be met.

From the perspective of organization, both relational and transactional contracts are possible. According to psychological contract theory (Rousseau, 1990), a multinational corporation needs excellent employees to work hard with loyalty, offer good performance in expected period have the capability of transferring know-how to other new staffs [23]. Therefore, the individual that the organizations view the psychological contracts between them as relational is the elite that is possible to become a director of the headquarters or group corporations. However, the potential of an employee of 30-45 years old is still not easy to judge. And some individuals of 30 years old don't have wonderful performance and experience and then he or she has little know-how to transfer to his or her juniors. Hence, for expatriates of 30-45 years old that are considered as elites, their multinational corporations will view the psychological contracts between them as relational. And they will get mixed success in repatriation but for their organization, failure in repatriation is very possible. On the contrary, for expatriates of 30-45 years old that are not considered as elites, their multinational corporations will view the psychological contracts between them as transactional. And in this case, the degree of repatriation success is just better than misalignment.

TABLE II: FRAMEWORK: AGE-BASED ORGANIZATION-INDIVIDUAL PSYCHOLOGICAL CONTRACTS UNDER INDIVIDUALISM ENVIRONMENT IN

\begin{tabular}{|c|c|c|c|c|}
\multicolumn{2}{c|}{ GLOBALIZATION } & \multicolumn{2}{c|}{ Organization } \\
\hline \multirow{2}{*}{} & Age & $\begin{array}{c}\text { Psychological } \\
\text { Contracts }\end{array}$ & Relational & Transactional \\
\cline { 2 - 5 } & $35-45$ & Transactional & II(P1) & IV(P2) \\
\cline { 2 - 5 } & $45-55$ & Balanced & I,II & III,IV \\
\cline { 2 - 5 } & & Relational & I(P3) & \\
\cline { 2 - 5 } & $>55$ & Transactional & & IV(P4) \\
\hline
\end{tabular}

Notes: I, II, III and IV have the same meaning as in Table I.

Proposition 3: For expatriates more than 55 years old that have been or will become directors of their multinational corporations or group companies, their organizations will view the psychological contracts between them as relational. And the expatriates will also view the psychological contracts between them as relational.

According to Liu (2002), in the decline stage ( $>55$ years old) an employee views the relationship with his or her organization as relational because they have built up good reliability with their organizations and have mutual loyalty [10]. But in fact, some of the employees more than 55 years old have to leave their organizations because they want to retire. On the other hand, some employees more than 55 years old have the willingness to stay and serve for their corporations continuously, but they cannot work on a fulltime job for some health problems or their salary are cut to half of the past for their age. It is difficult for these employees to offer good performance or serve with high motivation as expected by their organizations.

Therefore, only those who have become or are highly possible to become the directors of their corporations or group organizations can work as before continuously. These employees are able to offer good performance or serve with high motivation continuously as expected by their organizations. For these expatriates, they get promotion and good compensation and their expectations to the multinational corporations are highly met. Hence, they will view their psychological contracts as relational and serve for the corporation to the end of their career. And of course, they are willing to come back to their headquarters to utilize their experience or transfer their knowledge to their juniors there. From the perspective of organization, the ability and potentiality of an employee who's more than 55 years old can be judged clearly. In this case, if the multinational corporation agrees an employee to become its director, it must have relational psychological contract with him or her.

On the contrary, for employees more than 55 years, as it is difficult for them to offer good performance or serve with high motivation as expected by their organizations, their organizations will view the relationship between them as transactional. Because the ability and potentiality of an employee who's more than 55 years old can be judged clearly and he or she can hardly change the situation. At the same time, these employees may understand the situation of their organizations, and they will also view the relationship between them as transactional naturally. Therefore, compared with go back to work in the headquarters, expatriates in this case may prefer turning over to other companies to utilize their experience and transfer their knowledge to other juniors so that they can get a better compensation. Some of them will come back to the parent company country while some will stay in the host company country to continue their careers.

Proposition 4: For expatriates more than 55 years old that are not possible to become directors of their multinational corporations or group companies, their organizations will view the psychological contracts between them as transactional. And the expatriates will also view the psychological contracts between them as transactional.

As is known to all, psychological contract has the characteristics of changing. If an employee works hard and have better job performance than before, the expectation of the organization will be met better. Hence, it is possible for the organization to change their psychological contract to be relational with him or her. Specifically, if an expatriate of 
30-45 years get better performance on leadership, subordinate training ability, business operations, overseas marketing development, or technology transferring, the possibility that the organization expects him or her to come back to the headquarter after the period ends will increase in a significant way. On the contrary, an expatriate of this career stage makes a grave mistake in his or her expatriate assignment period; he or she will go in the opposite direction from what is expected. And the possibility that the expatriate comes back and gets promotion will decline. The degree of repatriation will come down.

For employees that are from 45 years to 55 years, Liu (2002) suggested that they view the psychological contracts with their organizations as balanced [10]. In this career stage, the characteristics of them are that, compared with promotion, most of them prefer keeping what they have achieved. They tend to maintain a kind of career stability and expect attractive welfare. From the perspective of organization, it needs to reserve some potential employees to bring them up to the leaders of it. In this case, it may view the psychological contract with these employees as relational. On the other hand, Some of the employees' performance are not very satisfactory, although they have served in the organization for a long period. In this case, the organization may view the psychological contract as transactional. Therefore, for expatriates that are from 45 years to 55 years, when they look out on repatriation, the four kinds of psychological contracts and four kinds of repatriation success are all possible. Expatriates of degree I may come back as scheduled to the headquarters to continue their career path to become respectable directors or managers. It is possible for expatriates of degree II to be headhunted by some middle-sized company and then quit to work in the new company and grow to its director or manager. This leads to some loss of the multinational corporations. Regarding to expatriates of degree III, after they come back to headquarter as scheduled at repatriation, maybe they will find there is no suitable position for them. This raises some problems to the expatriates' career and families. For expatriates of degree IV, at the timing of repatriation, they may quit to some other company. In this case, the organization faces some loss and meanwhile the expatriate has career problems such as demotion. But it is better than misalignment.

\section{Discussion}

While there were many empirical studies on expatriates' career building at repatriation, theoretic research in this area is insufficient. Based on career theory and psychological contract related research, this study offers a theoretical framework with four propositions for future research on expatriates' career and other international human resource management strategy. Through the analysis of three dimensions of individual, organizational and the globalization environment, these results provide practical implications for managing expatriates. Since expatriate assignments become more and more important in the coming days, multinational corporations' human resource managers should respect career and psychological contract issues when they are using expatriates.
As possible suggestions to raise the degree of repatriation success to human resource management strategy, HR managers should take a series of measures, for instance, doing long-term career plan, improving the compensation system, offering valuable jobs to increase expatriates' motivation, creating good training chance for expatriates to learn more and maintaining good interpersonal communication environment. At the same time, if the careers of expatriates are well designed, the multinational internal labor market will be stronger and the human resource mobility in an multinational corporation will be more active, which can enhance its efficiency and benefit its performance obviously.

Another implication of this research is to the aging society. In many developed and developing countries, aged individuals increase drastically. In expatriate assignment, there are more and more aged persons. How to manage their careers influences the stability of our society significantly. Multinational corporations may offer more and better chances for such aged individuals than some middle-sized or small-sized firms.

From the framework mode I developed in this paper, it seems that expatriates from 30 to 45 years are in low degree of repatriation success. Maybe this is a negative conclusion for young expatriates and multinational corporations that use them. In fact, it is in respect of individuals and organizations in an individualism culture environment. And for individuals and organizations in collectivism culture environment, the framework mode needs to be changed. Furthermore, maybe a small part of individuals in this career stage have the relational psychological contracts with his or her organization, and their career paths at repatriation will be better. Additionally, the psychological contracts between individual and organization have the characteristics of keeping changing. It is dynamic and will change with the degree of satisfaction. Therefore, young expatriates may keep working in an optimistic attitude and be confident of their own careers.

\section{Conclusions}

The purpose of this research is to offer a general framework mode based on review of the extant literature on expatriate career and psychological contracts. It is found that the age, psychological contracts, globalization and culture environment influence an expatriate's career path at repatriation. In different career stage, the psychological contracts between individual and organization are distinct.

The specific conclusion of this paper is as follows. For expatriates of 30-45 years old that are considered as elites, their multinational corporations will view the psychological contracts between them as relational. In this case, the organizational will fail in repatriation and the expatriate will get mixed success in repatriation. For expatriates of 30-45 years old that are not considered as elites, their multinational corporations will view the psychological contracts between them as transactional. In this case, the multinational organizational gets success in repatriation to some extent. And the expatriate will also succeed in repatriation to some extent. For expatriates more than 55 years old that have been 
or will become directors of their multinational corporations or group companies, their organizations will view the psychological contracts between them as relational. And the expatriates will also view the psychological contracts between them as relational. Their degree of repatriation success is high and it is possible for them to be successful in continued career development, attractive future assignments, promotion and enlargement of responsibility. At the same time, it is easy to realize retention of repatriated employee, utilization of new know-how, transfer of expertise for the multinational corporations. For expatriates more than 55 years old that are not possible to become directors of their multinational corporations or group companies, their organizations will view the psychological contracts between them as transactional. And the expatriates will also view the psychological contracts between them as transactional. This is the same with the case of expatriates of 30-45 years. Both the multinational organization and expatriates will succeed to some extent, but maybe that is not the best result as they expected. For employees that are from 45 years to 55 years, all the above-mentioned results are possible to happen to them. And the specific psychology contracts mode of them needs further analysis. This is also an issue remained to be resolved in the future research.

Furthermore, this research is not perfect and some other limitations are worth noting. First, the lack of sufficient empirical evidence in the areas of expatriates' career path at repatriation leaves some questions open to future research. It is necessary for us to do more case studies and even quantitative analysis. Second, using expatriates may reduce management cost between headquarters and its subsidiaries, and it is a necessary condition for the formation of multi-national internal labor markets. But using expatriate itself also takes cost. Therefore, further researches should try to solve the issue that how to balance the two kind of cost as well. Third, the framework I develop in this paper is under the culture environment of individualism and it will be very interesting to do research on individuals and organizations in collectivism culture environment.

For the researches in the future, the propositions in this research would be a reference. In conclusion, I believe there are sufficient expatriate related cases in multinational corporations and we may do better research in the future.

\section{REFERENCES}

[1] A. Yan, G. Zhu, and D. May, "International assignments for career building: A model of agency relationships and psychological contracts," Academy of Management Review, vol. 7, no. 3, pp. 373-386. 2002.

[2] D. Tan and J. T. Mahoney, "Why a multinational firm chooses expatriates: integrating resource-based, agency and transaction costs perspectives," Journal of Management Studies, vol. 43, no. 3, pp. 457-484, 2006

[3] Y. Tanzawa, Foundation of organization research, Hakuto Syobo, 2000, pp. 73-78.

[4] D. Tan and J. T. Mahoney, "Explaining the utilization of managerial expatriates from the perspectives of resource-based, agency, and transaction costs theories," Advances in International Management, vol. 15, no. 2, pp. 179-205, 2003.

[5] E. Carolyn and T. Ingemar, "A transaction costs perspective on international staffing patterns: implications for firm performance," Management International Review, vol. 39, pp. 89, 1999.

[6] R. G. B. Gabriel, "A transaction cost analysis of staffing decisions in international operations,” Scand. J. Mgmt., vol. 21, pp. 101-126, 2005.
[7] M. Shiraki, An analysis of International Human Resource Management: From the 'Multi-National Internal Labor Markets' Viewpoint, Yuhikaku Publishing Co., Ltd., 2006, pp. 27-30.

[8] M. B. Arthur, D. T. Hall, and B. S. Lawrence, Handbook of Career Theory, Cambridge: Cambridge University Press, 1989, ch. 3.

[9] E. H. Schein, Career Dynamics: Macthing Individual and Organizational Needs, Reading, MA: Addison-Wesley, Toshiko futamura, Katsuyo miyoshi translated, Hakuto Syobo, 1991, pp. 31-37.

[10] Y. Liu, "The characteristics and model of psychological contracts," Journal of Wuhan Economic Administration, Cader's College, vol. 16 no. 4, pp. 30-33, 2002.

[11] H. Okubayashi, Career Development and Human Resource Strategy, Chuo economic publication, 2004, pp. 136-138.

[12] V, Suutari and K. Makela, "The career capital of managers with global careers," Journal of Managerial Psychology, vol. 22, iss. 7, pp. 628-648, 2007.

[13] K. Ma"kela and V. Suutari, "Global careers: a social capital paradox," The International Journal of Human Resource Management, vol. 20, no. 5, pp. 992-1008, May 2009.

[14] C. Lan, H. Andreas, and D. Jürgen, "Self-initiated expatriates and their career success," The Journal of Management Development, vol. 31, no. 2, pp. 159-172, 2012.

[15] K. Inkson, M. B. Arthur, J. Pringle, and S. Barry, "Expatriate assignment versus overseas experience: contrasting models of human resource development," Journal of World Business, vol. 32, pp. 351-368, 1997.

[16] D. C. Thomas, M. B Lazarova, and K. Inkson, "Global careers: New phenomenon or new perspectives?" Journal of World Business, vol. 40, pp. $340-347,2005$.

[17] V. Suutairi and C. Brewster, "Making their own way: international experience through self-initiated foreign assignments," Journal of World Business, vol. 35, pp. 417-436, 2000.

[18] W.-B. Ursula and N. J. Beutell, "International assignments and the career management of repatriates: the boundaryless career concept," International Journal of Management, vol. 26, no. 1, pp. 77, April 2009.

[19] D. T. Hall, Careers in Organizations, Pacific Palisades, CA: Goodyear, 1976, ch. 2.

[20] D. T. Hall and Associates (Eds,), The Career is Dead---Long Live the Career: A Relational Approach to Careers, San Francisco: Jossey-Bass, 1996, ch. 2.

[21] A. Haslberger and C. Brewster, "Capital gains: expatriate adjustment and the psychological contract in in internatioanl careers," Human Resource Management, vol. 48, no. 3, pp. 379-397, May-June 2009.

[22] D. M. Rousseau, "Psychological and implied contracts in organizations," Employee Rights and Responsibilities Journal, vol. 2, no. 2, pp. 121-139, 1989.

[23] D. M. Rousseau, "New hire perceptions of their own and their employer's obligations: a study of psychological contracts," Journal of Organizational Behavior, vol. 11, iss. 5, pp. 389-400, 1990.

[24] E. H. Schein, Organizational Psychology, Englewood Cliffs, NJ: Prentice-Hall, 1965, ch. 3.

[25] H. Zhao, S. J. Wayne, B. Glibkowski, and J. Bravo, "The impact of psychological contract breach on work-related outcomes: a meta-analysis," Personnel Psychology, vol. 60, iss. 3, pp. 647-680, 2007.

[26] M. Gerber, G. Grote, C. Geiser, and S. Raeder, "Managing psychological contracts in the era of the new career," European Journal of Work and Organizational Psychology, vol. 21, no. 2, pp. 195-221, 2012.

[27] I. R. MacNeil, "Relational contract: what we do and do not know," Wisconsin Law Review, pp. 483-525, 1985.

[28] D. M. Rousseau, Psychological Contracts Inventory Technical Report, Pittsburgh: Carnegie Mellon University, 2000, pp. 37-68.

[29] J. G. Wang, "The influence of individual's culture characteristic to psychological contracts," Commercial Research, vol. 429, pp. 92-96, 2013.

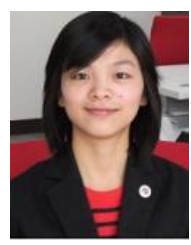

Yanghua Zhou worked in American and Japanese companies as HR specialist and consultant. Zhou has some published books and research papers. Yanghua Zhou is in the Graduate School of Policy Studies, Chuo University in Tokyo, Japan. She is also a member of Japan Academy of International Business Studies and Japan Society of Human Resource Management. 